\title{
ORGANIC SULFUR OXIDATION TO SULFATE IN SOIL SAMPLES FOR TOTAL SULFUR DETERMINATION BY TURBIDIMETRY(1)
}

\author{
Alexssandra Luiza Rodrigues Molina Rossete ${ }^{(2)}$, José Albertino \\ Bendassolli $^{(3)} \&$ Paulo Cesar Ocheuze Trivelin ${ }^{(4)}$
}

\begin{abstract}
Sulfur in the soil occurs in two basic forms, organic and inorganic S. The organic form accounts for $95 \%$ of $\mathrm{S}$ in most soils. The effectiveness of organic $\mathrm{S}$ to oxidate to sulfate was evaluated for total $S$ determination in soil samples by wet (acid) and dry-ash (alkaline) oxidation methods. To evaluate the wet method and the possible use as a reference when evaluating the dry method proposed here, a reference standard from the US National Institute of Standards and Technology (NIST) was used (Montana Soil - NIST 2710). The dry-ash oxidation process with alkaline oxidizing agents is one of the simplest oxidation methods of organic $\mathrm{S}$ to the sulfate form and was compared with the wet process. The objective of the study was to develop a dry method that would be easy to apply and allow the complete conversion of organic $S$ to sulfate in soil samples and later detection by turbidimetry. The effectiveness of organic S oxidation to sulfate was evaluated by means of three alkaline oxidation mixtures: $\mathrm{NaHCO}_{3}+\mathrm{Ag}_{2} \mathrm{O}$, Eschka mixture (17\% $\mathrm{Na}_{2} \mathrm{CO}_{3}, 66 \% \mathrm{MgO}$, and $17 \% \mathrm{~K}_{2} \mathrm{CO}_{3}$ ), and $\mathrm{NaHCO}_{3}+\mathrm{CuO}$. The procedure to quantify the sulfate concentration was based on the reaction with barium chloride and turbidimetric detection. Sulfur quantification in the standard sample by the wet method proved adequate, precise and accurate. It should also be pointed out that no significant differences were found (95\% reliability) between the wet and dry processes ( $\mathrm{NaHCO}_{3}$ and $\mathrm{Ag}_{2} \mathrm{O}$ oxidation mixture) in six different Brazilian soils. The proposed dry method can therefore be used in the preparation of soil samples for total S determination.
\end{abstract}

Index terms: sample preparation, turbidimetric method, spectrophotometry.

\footnotetext{
(1) Part of the first author's doctoral dissertation, presented to the graduate program in Science, Centro de Energia Nuclear na Agricultura - CENA/USP. Study funded by FAPESP. Received for publication in june 2007 and aproved in october 2008.

${ }^{(2)}$ Post-Doctoral Program in Science at Centro de Energia Nuclear na Agricultura - CENA/USP. Av. Centenário 303, CEP 13400970 Piracicaba (SP). E-mail: alrosset@cena.usp.br

(3) Associate Professor at Centro de Energia Nuclear na Agricultura, CENA/USP. E-mail: jab@cena.usp.br

${ }^{(4)}$ Associate Professor at Centro de Energia Nuclear na Agricultura, CENA/USP. E-mail: pcotrive@cena.usp.br
} 


\title{
RESUMO: OXIDAÇÃO DO ENXOFRE ORGÂNICO A SULFATO EM AMOSTRAS DE SOLO PARA DETERMINAÇÃO DE ENXOFRE TOTAL POR TURBIDIMETRIA
}

\begin{abstract}
O S no solo pode ocorrer como S-orgânico e S-inorgânico, sendo a forma orgânica responsável por $95 \%$ do $S$ na maioria dos solos. A eficiência da oxidação do S-orgânico a sulfato, na determinação de $S$-total em amostras de solo, foi avaliada com o emprego de métodos de oxidação por via úmida (ácida) e via seca (alcalina). Com o propósito de avaliar o método por via úmida e possivelmente empregá-lo como referência na avaliação do método por via seca, proposto no presente trabalho, fez-se uso de um padrão de referência da National Institute of Standards Tecnology (NIST), Montana Soil (NIST 2710). A oxidação por via seca com agentes oxidantes alcalinos é um dos métodos mais simples para oxidação de S-orgânico à forma de sulfato e foi comparado com o método por via úmida. O objetivo deste trabalho foi desenvolver um método de fácil execução que possibilite a determinação do elemento (S-total) em amostras de solo por turbidimetria. A avaliação da eficiência da oxidação do S-orgânico a sulfato foi realizada com três misturas oxidantes alcalinas: $\mathrm{NaHCO}_{3}+\mathrm{Ag}_{2} \mathrm{O}$, mistura Eschka (17\% de $\mathrm{Na}_{2} \mathrm{CO}_{3}$, $66 \%$ de $\mathrm{MgO}$ e $17 \%$ de $\mathrm{K}_{2} \mathrm{CO}_{3}$ ) e $\mathrm{NaHCO}_{3}+\mathrm{CuO}$. O procedimento na quantificação da concentração de sulfato foi baseado na reação com cloreto de bário e deteç̧ão por turbidimetria. A quantificação do $S$ na amostra-padrão, pelo uso do método por via úmida, mostrou-se adequada com boa precisão e exatidão. Deve-se ainda destacar que não foram encontradas diferenças significativas (confiabilidade de $95 \%$ ) entre os métodos por via úmida e via seca (mistura oxidante de $\mathrm{NaHCO}_{3}$ e $\mathrm{Ag}_{2} \mathrm{O}$ ) em seis diferentes solos brasileiros, o que possibilita o uso do método proposto por via seca no preparo de amostras de solos para determinação de $S$ total.
\end{abstract}

Termos de indexação: preparo de amostras, método turbidimétrico, espectrofotometria.

\section{INTRODUCTION}

Sulfur in the soil occurs in two basic forms, organic and inorganic S. Sulfur in the form of sulfate is readily available to plants, but organic S accounts for $95 \%$ of all $\mathrm{S}$ in most soils, as indicated by the close relations between organic C, total N, and total S (Beiderbeck, 1978). Organic S occurs in three forms: compounds with a S-O bond (sulfate esters); compounds with one S-C bond (amino acids), and compounds containing inert or residual S (Neptune et al., 1975; Beiderbeck, 1978; Freney, 1986). The main difficulty in quantifying total $\mathrm{S}$ in soil samples resides in the step where all organic $\mathrm{S}$ is converted to sulfate, since little is known about the nature of organic complexes.

The reserve $\mathrm{S}$ fraction (soluble sulfate and reducible forms) can be quantified using a method described by Alvarez V. et al. (2001), although the method underestimates the total values of $\mathrm{S}$ in the soil. Sulfur occluded in silicates or even insoluble $\mathrm{S}$ forms may not be extracted.

Several methods are used in the phase where all organic $\mathrm{S}$ is converted to sulfate. The most frequently employed procedures involve wet or dry-ash oxidation. Wet oxidation can be performed by acid or alkaline digestion. Acid digestion is a frequently used procedure in which the soil samples are heated to 190 to $210^{\circ} \mathrm{C}$ in a block digester in the presence of nitric and perchloric acid (Tabatabai, 1982). This digestion procedure requires precautions since it poses risks of explosion, fire, and material losses, which makes it inconvenient. In the alkaline digestion with an alkaline oxidizing agent, a sodium hypobromite solution is heated in a block digester to $250{ }^{\circ} \mathrm{C}$ (Tabatabai \& Bremner, 1970).

In another wet and acid oxidation method nitric and hydrochloric acid is used, in which organic S oxidation to sulfate in the soil samples occurs in the presence of these acids at $95^{\circ} \mathrm{C}$ in a block digester under reflux (Abreu et al., 2001).

Dry-ash oxidation using alkaline oxidizing agents is one of the simplest methods for oxidation of soil organic $\mathrm{S}$ to the sulfate form. In this method, soil samples are oxidized at $550{ }^{\circ} \mathrm{C}$ in the presence of an alkaline oxidizing agent, sodium bicarbonate and silver oxide (Steinbergs et al., 1962). Another possible alkaline agent is the Eschka mixture, which contains $17 \%$ sodium carbonate, $66 \%$ magnesium oxide, and $17 \%$ potassium carbonate (Mott \& Wilkinson, 1953).

The objective of this study was to develop a method of dry conversion of organic $\mathrm{S}$ into sulfate in soil samples and for total $\mathrm{S}$ detection by turbidimetry at a later time. 


\section{MATERIAL AND METHODS}

\section{Soil sampling and classification}

Different soil types, with sandy and clayey textures, were used to evaluate the total $\mathrm{S}$ determination method. Soil samples were collected from the top horizon (0-20 cm) at different inland locations in the State of São Paulo. The soils were classified according to the Brazilian Soil Classification System (Embrapa, 1999).

The soils were dried in a ventilated oven at $60^{\circ} \mathrm{C}$ for $48 \mathrm{~h}$, and sub samples were collected later. The importance of sub samples in soil samples must be emphasized, especially for S determination, due to the low concentration of this element in the soil. The soil samples were ground to particle sizes $<50 \mu \mathrm{m}$ in a ball mill (Abreu et al., 2001). Table 1 shows the different soil types, the municipality of the collection sites and the corresponding abbreviation.

The sampled soils were analyzed for soil chemistry, organic matter $(\mathrm{OM}), \mathrm{pH}$, exchangeable cations $\left(\mathrm{Ca}^{2+}\right.$, $\mathrm{Mg}^{2+}, \mathrm{K}^{+}$, and $\mathrm{Al}+\mathrm{H}$ ), and $\mathrm{P}$ (Abreu et al., 2001). Results of the soil fertility analyses performed at a laboratory of CENA/USP are shown in table 2.

The data in table 2 show considerable variations among the soil properties. The determinant factors of sulfate adsorption in the soil are mainly: soil $\mathrm{pH}$, type and mineral contents. Organic matter contents (OM) ranged from 10.8 to $29.6 \mathrm{~g} \mathrm{dm}^{-3}$; this is one of the fundamental properties for total $\mathrm{S}$ analyses. A second important property is the $\mathrm{pH}$, which ranged from 4.4 to 6.5 .

\section{Total sulfur determination in soil samples}

The oxidation of organic $\mathrm{S}$ to sulfate by the alkaline oxidation method (dry process) and variations were compared with the acid digestion process in a closed system.

Oxidation effectiveness was also evaluated using a $\mathrm{Na}_{2} \mathrm{SO}_{4}$ solution, to verify potential losses during the process (oxidation, extraction, filtration, and analytical determination). An L-cysteine solution
Table 2. Chemical analysis of soil samples

\begin{tabular}{|c|c|c|c|c|c|c|c|}
\hline Soil & $\mathbf{P}$ & $\mathbf{p H}$ & OM & $\mathrm{Ca}$ & Mg & $\mathbf{K}$ & $\mathbf{A l}+\mathbf{H}$ \\
\hline & $\mathrm{mg} \mathrm{dm}{ }^{-3}$ & & $\mathrm{~g} \mathrm{dm}^{-3}$ & 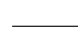 & $-\mathrm{mmol}_{\mathrm{c}}$ & $\mathrm{dm}^{-3}$ & - \\
\hline $\mathrm{LVe}$ & 67,6 & 4,4 & 24,5 & 11,4 & 4,4 & 5,3 & 77,9 \\
\hline NQo & 19,3 & 4,7 & 10,8 & 5,8 & 3,4 & 0,6 & 18,9 \\
\hline $\mathrm{NVe}$ & 9,6 & 4,6 & 29,6 & 24,2 & 12,3 & 2,4 & 63,3 \\
\hline LVEd & 20,7 & 5,4 & 18,3 & 36,6 & 30,5 & 1,7 & 29,9 \\
\hline AVAd & 54,4 & 6,5 & 20,3 & 66,0 & 37,9 & 3,3 & 14,9 \\
\hline AVEd & 168 & 52 & 192 & 358 & 173 & 20 & 285 \\
\hline
\end{tabular}

- an amino acid containing a S-C bond - was used to determine the effectiveness of organic S oxidation.

The difficulty in defining the most suitable oxidation method of organic S to sulfate, aimed at determining total $\mathrm{S}$ in soil samples, is mainly related to the variability of the analytical results, as a consequence of the different methods used. The proposed methods and the acid digestion (wet method) were compared by the Tukey test $(p<0.05)$.

\section{Wet digestion}

\section{Nitric digestion in a closed system}

The method consisted in nitric digestion, in a closed system, microwave-assisted high pressure Teflon bomb digestion. The $\mathrm{S}$ in the extract was quantified by inductively coupled plasma-atomic emission spectrometry (ICP-AES).

To evaluate the wet conversion method and detection by ICP-AES, a reference standard from the National Institute on Standards and Technology (NIST) was used (Montana Soil - NIST 2710). The Standard Reference Material had a total S content of $0.240 \pm 0.006 \%\left(2.400 \pm 60 \mathrm{mg} \mathrm{kg}^{-1}\right)$. The certified concentrations are based on measurements obtained by two or more independent methods or techniques.

It is however important to point out that this standard corresponds to highly contaminated ovendried soil that was sifted and mixed until a high degree of homogeneity was achieved. The analysis certificate

Table 1. Soil type, nomenclature, and counties of sample collections

\begin{tabular}{lll}
\hline \multicolumn{1}{c}{ Soil $^{(1)}$} & Nomenclature & City \\
\hline Latossolo Vermelho eutroférrico & LVe & Ribeirão Preto \\
Neossolo Quartzarênico órtico & NQo & Cravinhos \\
Nitossolo Vermelho eutroférrico & NVe & Ribeirão Preto \\
Latossolo Vermelho-Escuro distrófico & LVEd & Piracicaba \\
Argissolo Vermelho-Amarelo distrófico & AVAd & PVEd \\
Argissolo Vermelho-Escuro distrófico & Piracicaba & \\
\hline
\end{tabular}

(1) Brazilian Soil Classification System - Embrapa (1999). 
for the NIST 2710 standard indicates that the sample had been collected from the $0-10 \mathrm{~cm}$ soil profile of a pasture $\left(112^{\circ}\right.$ longitude and $46^{\circ}$ latitude) along the Silver Bow Creek near Butte, Montana. Periodically, sediments with high $\mathrm{Cu}, \mathrm{Mn}$, and $\mathrm{Zn}$ concentrations are deposited by the creek at the site where the standard sample was collected.

Initially, $3 \mathrm{~mL}$ concentrated nitric acid were added to the soil samples or standards $(0.5 \mathrm{~g})$; the samples were left to stand for 15 min before closing the Teflon vessels and proceeding to digestion in the microwave oven. At the end of digestion, the vessel was cooled until a pressure of about $69 \mathrm{kPa}$ was reached; then the lid was carefully removed. Next, the volume was adjusted to $50 \mathrm{~mL}$ with deionized water and $\mathrm{S}$ was quantified by ICP-AES.

\section{Dry-ash oxidation}

The effectiveness of organic S oxidation to sulfate was evaluated by means of three oxidation mixtures: $\mathrm{NaHCO}_{3}+\mathrm{Ag}_{2} \mathrm{O}$, Eschka mixture $\left(17 \% \mathrm{Na}_{2} \mathrm{CO} 3\right.$, $66 \% \mathrm{MgO}$, and $17 \% \mathrm{~K}_{2} \mathrm{CO}_{3}$ ), and $\mathrm{NaHCO}_{3}+\mathrm{CuO}$. The third oxidation mixture $\left(\mathrm{NaHCO}_{3}+\mathrm{CuO}\right)$ was used to evaluate a less costly method for conversion of organic S to sulfate in the six soil samples (Table 1), for later total $\mathrm{S}$ determination by turbidimetry.

\section{Oxidation mixtures $\mathrm{NaHCO}_{3}$ and $\mathrm{Ag}_{2} \mathrm{O}$}

Organic $\mathrm{S}$ in the soil samples was oxidized to sulfate by thermal combustion, in the presence of $\mathrm{NaHCO}_{3}$ (alkaline medium) and the oxidizing agent $\mathrm{Ag}_{2} \mathrm{O}$. Initially, we evaluated the influence of the ratio between $\mathrm{S}$ in the sample and the oxidation mixture on mass ratios of $1: 1000$ and 1:2000 (S: $\mathrm{NaHCO}_{3}+$ $\left.\mathrm{Ag}_{2} \mathrm{O}\right)$. The mass ratio between the reagents was $10 /$ $1\left(\mathrm{NaHCO}_{3} / \mathrm{Ag}_{2} \mathrm{O}\right)$. The temperature influence was evaluated between 550 and $800{ }^{\circ} \mathrm{C}$, at burning times of 5 and $8 \mathrm{~h}$ for sample oxidation in a furnace.

The soil sample (5.0 g) and the $\mathrm{NaHCO}_{3} / \mathrm{Ag}_{2} \mathrm{O}$ mixture, at a ratio of $2.0 / 0.2 \mathrm{~g}$, were filled in porcelain crucibles (diameter $11 \mathrm{~cm}$ ) and homogenized. To obtain the analytical calibration curve (for $2.5 ; 5 ; 10$; 15; and $20 \mathrm{mg} \mathrm{L}^{-1} \mathrm{~S}_{-} \mathrm{SO}_{4}^{-2}$ ) the reagents $\mathrm{NaHCO}_{3}$ and $\mathrm{Ag}_{2} \mathrm{O}$ were burned as described for the samples.

Solutions containing $500 \mathrm{mg} \mathrm{L}^{-1} \mathrm{~L}$-cysteine, $500 \mathrm{mg} \mathrm{L}^{-1} \mathrm{Na}_{2} \mathrm{SO}_{4}$, and $1000 \mathrm{mg} \mathrm{L}^{-1} \mathrm{~L}$-cysteine and $\mathrm{Na}_{2} \mathrm{SO}_{4}$ were prepared to verify the effectiveness of the alkaline, dry-ash oxidation. The solutions were filled in porcelain crucibles on the $\mathrm{NaHCO}_{3} / \mathrm{Ag}_{2} \mathrm{O}$ mixture. The homogenized samples were combusted at 550 and $650{ }^{\circ} \mathrm{C}$ in a furnace for 5 and $8 \mathrm{~h}$, where the oxidation of organic $\mathrm{S}$ to sulfate occurred.

At the end of the burning period and after the samples had cooled down to room temperature, the sulfate was solubilized with $30 \mathrm{~mL}$ of a $0.15 \% \mathrm{CaCl}_{2}$ solution $(\mathrm{m} / \mathrm{v})$ and $1.0 \mathrm{~g}$ activated charcoal. The activated charcoal was used to remove potential color residues from the soils. This procedure was performed under agitation for $15 \mathrm{~min}$ at $200 \mathrm{rpm}$. At the end of the agitation period, another $20 \mathrm{~mL} \mathrm{CaCl}_{2}$ solution was added and the extract was filtered through a cellulose ester filter (45.10-3 $\mathrm{m}$ diameter and $0.4510^{-6} \mathrm{~m}$ mesh). After filtration, $\mathrm{S}_{-} \mathrm{SO}_{4}{ }^{-2}$ was quantified in a $10 \mathrm{~mL}$ aliquot of the filtrate, enriched with $1 \mathrm{~mL} 6.0 \mathrm{~mol} \mathrm{~L}^{-1}$ $\mathrm{HCl}$ solution containing $20 \mathrm{mg} \mathrm{L}^{-1} \mathrm{~S}$ to facilitate the nucleation process.

After $30 \mathrm{~s}, 0.50 \mathrm{~g} \mathrm{BaCl}_{2} \cdot 2 \mathrm{H}_{2} \mathrm{O}$ was added and the solution was then transferred to the spectrophotometer cuvette; readings were obtained at $420 \mathrm{~nm}$, at a maximum time of 8 min after the $\mathrm{BaCl}_{2} \cdot 2 \mathrm{H}_{2} \mathrm{O}$ had been added. Based on the turbidity readings for the filtrate and using the analytical calibration curve, the $\mathrm{S}-\mathrm{SO}_{4}{ }^{2-}$ concentration that corresponded to the total $\mathrm{S}$ content in the soil samples could be determined (Abreu et al., 2001).

\section{Oxidation mixtures $\mathrm{NaHCO}_{3}$ and $\mathrm{CuO}$}

The organic $\mathrm{S}$ in the soil samples was oxidized to sulfate by thermal combustion in the presence of the agents $\mathrm{NaHCO}_{3}$ and $\mathrm{CuO}$. Initially the influence of the ratio of $\mathrm{S}$ in the sample and the oxidation mixture was evaluated at a mass ratio of 1:1000 (S: $\mathrm{NaHCO}_{3}$ $+\mathrm{CuO})$. The mass ratio between reagents was $10 / 1$ and $10 / 2\left(\mathrm{NaHCO}_{3} / \mathrm{CuO}\right)$. The influence of temperature $\left(550\right.$ and $\left.650{ }^{\circ} \mathrm{C}\right)$ on sample oxidation was evaluated as well.

Solutions containing $500 \mathrm{mg} \mathrm{L}^{-1}$ L-cysteine, $500 \mathrm{mg} \mathrm{L}^{-1} \mathrm{Na}_{2} \mathrm{SO}_{4}$, and $1000 \mathrm{mg} \mathrm{L}^{-1} \mathrm{~L}$-cysteine and $\mathrm{Na}_{2} \mathrm{SO}_{4}$ were prepared to verify the effectiveness of the alkaline dry-ash oxidation. The solutions were filled in porcelain crucibles on the $\mathrm{NaHCO}_{3} / \mathrm{CuO}$ mixture.

The soil sample $(5.0 \mathrm{~g})$ and the $\mathrm{NaHCO}_{3} / \mathrm{CuO}$ mixture, at ratios of $2.0 / 0.2 \mathrm{~g}$ and $2.0 / 0.4 \mathrm{~g}$, were filled into porcelain crucibles (diameter $11 \mathrm{~cm}$ ) and homogenized. The analytical calibration curve (for 2.5; 5; 10; 15 ; and $20 \mathrm{mg} \mathrm{L}^{-1} \mathrm{~S}_{-} \mathrm{SO}_{4}^{-2}$ ) was established, as described for the $\mathrm{NaHCO}_{3}$ and $\mathrm{Ag}_{2} \mathrm{O}$ oxidation mixture.

After homogenization, the samples were combusted in a furnace for $8 \mathrm{~h}$. The samples were solubilized and sulfate determined as described for the oxidation mixtures $\mathrm{NaHCO}_{3}$ and $\mathrm{Ag}_{2} \mathrm{O}$.

\section{Eschka Mixture $\left(\mathrm{Na}_{2} \mathrm{HCO}_{3}, \mathrm{MgO}\right.$, and $\left.\mathrm{K}_{2} \mathrm{CO}_{3}\right)$}

The organic $\mathrm{S}$ in the soil samples was oxidized to sulfate by combustion using Eschka mixture. The influence of the mass ratio between the soil sample and the mass of the Eschka mixture (1:1, 1:2, and 1:4) was evaluated.

Five $\mathrm{g}$ of soil sample containing approximately 600 to $900 \mu \mathrm{g} \mathrm{S}$, and $10 \mathrm{~g}$ Eschka mixture, at a ratio of 1:2 were filled in porcelain crucibles (diameter $11 \mathrm{~cm}$ ). The analytical calibration curve (for $5 ; 10 ; 15$; and $20 \mathrm{mg} \mathrm{L}^{-1} \mathrm{~S}_{-} \mathrm{SO}_{4}^{-2}$ ) was obtained by burning the Eschka mixture. 
After homogenizing the samples, combustion was performed at $800^{\circ} \mathrm{C}$ in a furnace for $1 \mathrm{~h}$, during which organic S oxidation occurred; sulfate was determined, as described for the $\mathrm{NaHCO}_{3}$ and $\mathrm{Ag}_{2} \mathrm{O}$ oxidation mixture.

\section{RESULTS AND DISCUSSION}

\section{Nitric digestion in closed system}

The total $\mathrm{S}$ values were evaluated in soil samples and standards by nitric digestion in a closed system, using Teflon bombs heated in a microwave oven (Table 3). These results were compared with those obtained by the oxidation of organic $\mathrm{S}$ to sulfate in the different procedures described above.

Based on the results obtained for the NIST reference material, it can be considered that the wet method of soil sample preparation in a closed system is an effective method for conversion of organic S into sulfate and determination of total $\mathrm{S}$ at a later time. Consequently, the wet method can be used as a standard procedure to validate the dry method, which was one of the objectives of our study.

\section{Oxidation mixtures $\mathrm{NaHCO}_{3}$ and $\mathrm{Ag}_{2} \mathrm{O}$}

The results of determinations using inorganic $\mathrm{S}$ or organic S solutions are given in table 4 , as well as the $\mathrm{S}$ concentrations and alkaline oxidation yield in L-cysteine and $\mathrm{Na}_{2} \mathrm{SO}_{4}$ solutions after combustion at $550{ }^{\circ} \mathrm{C}$ for $8 \mathrm{~h}$, using $2.0 \mathrm{~g} \mathrm{NaHCO}_{3}$ and $0.2 \mathrm{~g} \mathrm{Ag}_{2} \mathrm{O}$. These results indicated that oxidation yield was $99 \pm 2 \%$, using the mixture containing Ag; in other words, a quantitative recovery of $\mathrm{S}$ occurred from the L-cysteine and $\mathrm{Na}_{2} \mathrm{SO}_{4}$ mixture.

Burning temperatures of 750 and $800{ }^{\circ} \mathrm{C}$ were tested, based on the initial test results. The burningtemperature test results proved unsatisfactory, since bicarbonate fusion was observed, preventing the use

Table 3. Total S of soils by nitric digestion in a closed system $(n=4)$

\begin{tabular}{lccc}
\hline Soil & \multicolumn{2}{c}{ Concentration } \\
\hline \multicolumn{3}{c}{$\mathrm{mg} \mathrm{kg}^{-1}$} \\
LVe & 322.0 & \pm & 6.6 \\
NQo & 79.2 & \pm & 8.2 \\
NVe & 198.9 & \pm & 7.9 \\
LVEd & 192.2 & \pm & 2.9 \\
AVAd & 155.8 & \pm & 6.7 \\
AVEd & 164.1 & \pm & 2.6 \\
NIST 2710 & 2.500 & \pm 100
\end{tabular}

of mixtures containing $\mathrm{Ag}_{2} \mathrm{O}$ and $\mathrm{CuO}$. Therefore, we chose to evaluate temperatures of 550 and $650{ }^{\circ} \mathrm{C}$.

Based on the satisfactory results obtained (Table 3 ), the soil samples were submitted to the tests (Table 1) and the total S values for the soil samples evaluated at an oxidation temperature of $550{ }^{\circ} \mathrm{C}$ and reaction times of 5 and $8 \mathrm{~h}$ (Table 5).

There was no significant difference between the wet (acid digestion) and dry-ash (alkaline oxidation) methods at a burning temperature of $550{ }^{\circ} \mathrm{C}$ for $8 \mathrm{~h}$ (Table 5). With regard to the burning temperature of $550{ }^{\circ} \mathrm{C}$ for a reaction time of $5 \mathrm{~h}$, the methods were different (at the $5 \%$ level) in most soils.

The alkaline oxidation occurred at a temperature of $650{ }^{\circ} \mathrm{C}$ and burning times of 8 and $5 \mathrm{~h}$ (Table 6). These results were obtained using $2.0 \mathrm{~g} \mathrm{NaHCO}_{3}$ and $0.2 \mathrm{~g} \mathrm{Ag}_{2} \mathrm{O}$, indicating that results by acid digestion (wet) method differed significantly in most soils from the alkaline oxidation (dry-ash) method, at a burning temperature of $650^{\circ} \mathrm{C}$ for a combustion time of $5 \mathrm{~h}$.

For $8 \mathrm{~h}$ of reaction, results still indicated significant differences between the methods (wet and dry-ash) in three of the soils evaluated. At the highest temperature $\left(650{ }^{\circ} \mathrm{C}\right) \mathrm{S}$ losses may have been facilitated, a fact observed in four of the six soils.

Table 4. Total S and alkaline oxidation yield with a mixture containing $\mathrm{NaHCO}_{3} / \mathrm{Ag}_{2} \mathrm{O}(\mathrm{n}=5)$

\begin{tabular}{|c|c|c|}
\hline Sample & Concentration & S Recovery ${ }^{(1)}$ \\
\hline & $\mathrm{mg} \mathrm{L} \mathrm{L}^{-1} \mathrm{~S}-\mathrm{SO}_{4}$ & $\%$ \\
\hline L-Cysteine & $475,6 \pm 4,9$ & $95 \pm 1$ \\
\hline Sodium sulfate & $472,5 \pm 9,5$ & $95 \pm 2$ \\
\hline L-Cysteine + Sodium sulfate & $989,5 \pm 16$ & $99 \pm 2$ \\
\hline
\end{tabular}

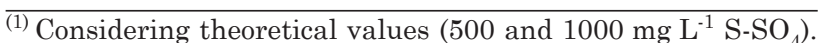
$\mathrm{n}$ : number of replications for each sample.

Table 5. Total $\mathrm{S}$ by acid and alkaline digestion, using a $\mathrm{NaHCO}_{3}+\mathrm{Ag}_{2} \mathrm{O}$ oxidation mixture (2.0/0.2 g) at a temperature of $550{ }^{\circ} \mathrm{C}(\mathrm{n}=5)$

\begin{tabular}{lrrrr}
\hline & & \multicolumn{3}{c}{ Alkaline digestion } \\
\cline { 2 - 5 } Soil & Acid digestion & $\mathbf{5} \mathbf{~ h}$ & $\mathbf{8 ~ h}$ \\
\hline & & $\mathrm{mg} \mathrm{k}^{-1}$ soil & \\
\cline { 2 - 5 } LVe & $322.0 \pm 6.6 \mathrm{a}$ & $259.1 \pm 18.1 \mathrm{~b}$ & $319.6 \pm 15.0 \mathrm{a}$ \\
NQo & $79.2 \pm 8.2 \mathrm{a}$ & $34.9 \pm 5.5 \mathrm{~b}$ & $67.0 \pm 9.4 \mathrm{a}$ \\
NVe & $198.9 \pm 7.9 \mathrm{a}$ & $198.3 \pm 6.4 \mathrm{a}$ & $227.2 \pm 7.7 \mathrm{a}$ \\
LVEd & $192.2 \pm 2.9 \mathrm{a}$ & $143.5 \pm 5.7 \mathrm{~b}$ & $191.4 \pm 14.6 \mathrm{a}$ \\
AVAd & $155.8 \pm 6.7 \mathrm{a}$ & $105.1 \pm 13.9 \mathrm{~b}$ & $156.3 \pm 2.2 \mathrm{a}$ \\
AVEd & $164.1 \pm 2.6 \mathrm{a}$ & $137.9 \pm 3.3 \mathrm{a}$ & $164.6 \pm 6.1 \mathrm{a}$ \\
\hline
\end{tabular}

Means between treatments in the rows, followed by different letters are different from each other at the $5 \%$ level by Tukey test. 
Table 6. Total $\mathrm{S}$ by acid and alkaline digestion, using a $\mathrm{NaHCO}_{3}+\mathrm{Ag}_{2} \mathrm{O}$ oxidation mixture (2.0/0.2 g) at a temperature of $650^{\circ} \mathrm{C}(\mathrm{n}=5)$

\begin{tabular}{lrrrr}
\hline \multirow{2}{*}{ Soil } & Acid digestion & \multicolumn{3}{c}{ Alkaline digestion } \\
\cline { 2 - 5 } & \multicolumn{4}{c}{$\mathbf{5} \mathbf{~ h}$} \\
\hline & $\mathrm{mg} \mathrm{kg}^{-1}$ soil \\
\cline { 2 - 5 } & & \multicolumn{2}{c}{$\mathbf{~ h}$} \\
LVe & $322,0 \pm 6,6 \mathrm{ab}$ & $288,3 \pm 6,5 \mathrm{a}$ & $358,6 \pm 18,3 \mathrm{~b}$ \\
NVe & $79,2 \pm 8,2 \mathrm{a}$ & $38,5 \pm 3,4 \mathrm{~b}$ & $54,8 \pm 3,4 \mathrm{c}$ \\
LVEd & $198,9 \pm 7,9 \mathrm{a}$ & $198,0 \pm 8,2 \mathrm{a}$ & $264,9 \pm 19,3 \mathrm{~b}$ \\
AVAd & $155,8 \pm 6,7 \mathrm{a}$ & $69,2 \pm 5,8 \mathrm{~b}$ & $141,4 \pm 14,9 \mathrm{a}$ \\
AVEd & $164,1 \pm 2,6 \mathrm{a}$ & $80,7 \pm 7,9 \mathrm{~b}$ & $119,0 \pm 18,8 \mathrm{c}$ \\
\hline
\end{tabular}

Means between treatments in the rows, followed by different letters are different from each other at the $5 \%$ level by Tukey test.

In the oxidation tests where the mixture of $4.0 \mathrm{~g}$ $\mathrm{NaHCO}_{3}$ and $0.4 \mathrm{~g} \mathrm{Ag}_{2} \mathrm{O}$ (1:2000 ratio) was used at a burning temperature of $550{ }^{\circ} \mathrm{C}$ for 5 and $8 \mathrm{~h}$, no satisfactory results were obtained, since excess carbonate was measured in the extract. The volume of hydrochloric acid used for turbidimetry was therefore not sufficient to release carbonate completely, resulting in the formation of barium carbonate, hampering the spectrophotometric readings.

\section{Oxidation mixtures $\mathrm{NaHCO}_{3}$ and $\mathrm{CuO}$}

The total $\mathrm{S}$ determination in samples of various soils by dry-ash oxidation, using an oxidation mixture containing $2.0 \mathrm{~g} \mathrm{NaHCO}_{3}$ and $0.2 \mathrm{~g} \mathrm{CuO}$, with a 1:1000 ratio between $\mathrm{S}$ in the sample and the reagents, were evaluated at burning temperatures of 550 and $650{ }^{\circ} \mathrm{C}$ and an oxidation time of $8 \mathrm{~h}$.

Sulfur concentrations and alkaline oxidation yields of L-cysteine and $\mathrm{Na}_{2} \mathrm{SO}_{4}$ solutions indicated a quantitative $\mathrm{S}$ recovery, after combustion at $550^{\circ} \mathrm{C}$ for $8 \mathrm{~h}$ using $2.0 \mathrm{~g} \mathrm{NaHCO}_{3}$ and $0.2 \mathrm{~g} \mathrm{CuO}$ (Table 7).

Table 8 shows total $\mathrm{S}$ values obtained from soil samples, at oxidation temperatures of 550 and $650{ }^{\circ} \mathrm{C}$ and a reaction time of $8 \mathrm{~h}$. The statistical analysis indicated significant differences in two soils only (NQo and $\mathrm{NVe}$ ) between the acid and the alkaline oxidation method $\left(\mathrm{NaHCO}_{3}+\mathrm{CuO}\right)$ at a burning temperature of $550{ }^{\circ} \mathrm{C}$ and combustion time of $8 \mathrm{~h}$. In the trials conducted at an oxidation temperature of $650{ }^{\circ} \mathrm{C}$, the methods were different in four of the six soils.

Considering the results obtained with the $\mathrm{NaHCO}_{3}$ and $\mathrm{CuO}$ mixture (Table 8 ), the mass ratio between reagents was changed $\left(\mathrm{NaHCO}_{3} / \mathrm{CuO}: 10 / 2\right)$ to evaluate the efficiency of the method, since the $\mathrm{S}$ contents in most soils were lower than in the reference method, including those obtained under the same conditions, $550{ }^{\circ} \mathrm{C}$ and $8 \mathrm{~h}$, using $\mathrm{Ag}_{2} \mathrm{O}$ (Table 5). These data might be an indication of oxidation deficiency, probably due to the oxygen supplied by the solid source used $(\mathrm{CuO})$.
Table 9 shows the values of total $\mathrm{S}$ determination with a modified reagent mass ratio $\left(\mathrm{NaHCO}_{3} / \mathrm{CuO}: 10 / 2\right)$. Results indicated a significant difference in five soils when compared to the values obtained at a mass ratio of $10 / 1$. When twice the amount of $\mathrm{CuO}(10 / 2)$ was used, the total $S$ values were lower than when obtained at a ratio of 10/1.

Table 7. Sulfur concentration and alkaline oxidation yield using $\mathrm{NaHCO}_{3}+\mathrm{CuO}$ oxidation mixtures $(n=5)$

\begin{tabular}{lcc}
\hline \multicolumn{1}{c}{ Sample } & Concentration & S Recovery $^{(1)}$ \\
\hline & $\mathrm{mg} \mathrm{L}^{-1} \mathrm{~S}-\mathrm{SO}_{4}$ & $\%$ \\
& $460,2 \pm 16,9$ & $92 \pm 3$ \\
L-Cysteine & $456,4 \pm 13,8$ & $92 \pm 3$ \\
Sodium sulfate & $957,7 \pm 42,9$ & $96 \pm 4$
\end{tabular}

(1) Considering theoretical values (500 and $1000 \mathrm{mg} \mathrm{L}^{-1} \mathrm{~S}_{-} \mathrm{SO}_{4}$ ). $\mathrm{n}$ : number of replications for each sample.

Table 8. Total $\mathrm{S}$ by acid and alkaline digestion using an oxidation mixture of $\mathrm{NaHCO}_{3}+\mathrm{CuO}(2.0 /$ $0.2 \mathrm{~g}$ ), at temperatures of 550 and $650{ }^{\circ} \mathrm{C}$, and an oxidation time of $8 \mathrm{~h}(n=5)$

\begin{tabular}{|c|c|c|c|}
\hline \multirow{2}{*}{ Soil } & \multirow{2}{*}{ Acid digestion } & \multicolumn{2}{|c|}{ Alkaline digestion } \\
\hline & & $550{ }^{\circ} \mathrm{C}$ & $650{ }^{\circ} \mathrm{C}$ \\
\hline & & — $\mathrm{mg} \mathrm{kg}^{-1}$ soil & $c_{1}$ \\
\hline $\mathrm{LVe}$ & $322,0 \pm 6,6 \mathrm{ab}$ & $295,1 \pm 13,1 \mathrm{a}$ & $352,0 \pm 25,2 \mathrm{~b}$ \\
\hline NQo & $79,2 \pm 8,2 \mathrm{a}$ & $44,7 \pm 8,1 \mathrm{~b}$ & $39,9 \pm 5,2 \mathrm{c}$ \\
\hline $\mathrm{NVe}$ & $198,9 \pm 7,9 \mathrm{a}$ & $240,7 \pm 9,4 \mathrm{~b}$ & $235,7 \pm 4,1 \mathrm{a}$ \\
\hline LVEd & $192,2 \pm 2,9 \mathrm{a}$ & $165,0 \pm 7,0 \mathrm{a}$ & $155,4 \pm 4,3 \mathrm{a}$ \\
\hline AVAd & $155,5 \pm 6,7 \mathrm{a}$ & $130,1 \pm 1,3 \mathrm{a}$ & $110,3 \pm 12,9 \mathrm{~b}$ \\
\hline AVEd & $164,1 \pm 2,6 \mathrm{a}$ & $139,8 \pm 3,3 \mathrm{a}$ & $131,6 \pm 10,7 \mathrm{~b}$ \\
\hline
\end{tabular}

Means between treatments in the rows, followed by different letters are different from each other at the $5 \%$ level by Tukey test.

Table 9. Total $\mathrm{S}$ by acid and alkaline digestion using an oxidation mixture of $\mathrm{NaHCO}_{3}+\mathrm{CuO}$ (ratios of $10 / 1$ and $10 / 2)$, at $550{ }^{\circ} \mathrm{C}$ for $8 \mathrm{~h}(\mathrm{n}=4)$

\begin{tabular}{|c|c|c|c|}
\hline \multirow{2}{*}{ Soil } & \multirow{2}{*}{ Acid digestion } & \multicolumn{2}{|c|}{$\mathrm{NaHCO}_{3} / \mathrm{CuO}$} \\
\hline & & $2.0 / 0.2 \mathrm{~g}$ & $2.0 / 0.4 \mathrm{~g}$ \\
\hline & & - $\mathrm{mg} \mathrm{kg}^{-1}$ soil & 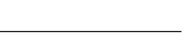 \\
\hline $\mathrm{LVe}$ & $322,0 \pm 6,6 \mathrm{ab}$ & $314,3 \pm 13,1 \mathrm{a}$ & $295,6 \pm 33,0 \mathrm{~b}$ \\
\hline NQo & $79,2 \pm 8,2 \mathrm{a}$ & $51,89 \pm 8,1 \mathrm{~b}$ & $42,6 \pm 4,7 \mathrm{c}$ \\
\hline $\mathrm{NVe}$ & $198,9 \pm 7,9 \mathrm{a}$ & $247,9 \pm 9,4 \mathrm{~b}$ & $228,3 \pm 0,6 \mathrm{a}$ \\
\hline LVEd & $192,2 \pm 2,9 \mathrm{a}$ & $172,21 \pm 7,0 \mathrm{a}$ & $161,9 \pm 8,6 \mathrm{~b}$ \\
\hline AVAd & $155,8 \pm 6,7 \mathrm{a}$ & $137,3 \pm 1,3 \mathrm{~b}$ & $134,3 \pm 7,2 \mathrm{~b}$ \\
\hline AVEd & $164,1 \pm 2,6 \mathrm{a}$ & $147,04 \pm 3,3 \mathrm{a}$ & $134,8 \pm 3,7 b$ \\
\hline
\end{tabular}

Means between treatments in the rows, followed by different letters are different from each other at the $5 \%$ level by Tukey test. 


\section{Eschka Mixture $\left(\mathrm{Na}_{2} \mathrm{HCO}_{3}, \mathrm{MgO}\right.$, and $\left.\mathrm{K}_{2} \mathrm{CO}_{3}\right)$}

The total $\mathrm{S}$ values using $5 \mathrm{~g}$ of soil sample and a mass of 5 or $10 \mathrm{~g}$ of the Eschka mixture (1/1 and 1/2) are given in table 10 . The statistical analysis indicated that results differed from each other in $50 \%$ of the soils evaluated (95\% reliability).

Based on our results (Table 10), it was observed that as the mass ratio between the sample and the mixture changed (1/1), results of most soils analyzed were reduced, compared to those obtained at a ratio of $1 / 2$, indicating incomplete oxidation of organic $\mathbf{S}$ to sulfate.

Results of total $\mathrm{S}$ determination using $5 \mathrm{~g}$ soil and $20 \mathrm{~g}$ Eschka mixture (1/4) were not satisfactory, since the excess carbonate in the extract prevented determination by turbidimetry.

Table 10. Total $\mathrm{S}$ by alkaline oxidation using the Eschka mixture (ratios of $1 / 1$ and $1 / 2$ ) at $800^{\circ} \mathrm{C}$ for $1 \mathrm{~h}(\mathrm{n}=4)$

\begin{tabular}{lrrr}
\hline Soil & Acid digestion & $\mathbf{1 / 1}$ Ratio & 1/2 Ratio \\
& \multicolumn{3}{c}{$\mathrm{mg} \mathrm{kg}^{-1}$ soil } \\
\cline { 2 - 4 } LVe & $322,0 \pm 6,6 \mathrm{a}$ & $331,2 \pm 6,6 \mathrm{a}$ & $374,6 \pm 19,7 \mathrm{a}$ \\
NQo & $79,2 \pm 8,2 \mathrm{a}$ & $45,9 \pm 1,0 \mathrm{~b}$ & $45,8 \pm 2,6 \mathrm{~b}$ \\
NVe & $198,9 \pm 7,9 \mathrm{a}$ & $264,3 \pm 28,8 \mathrm{~b}$ & $289,7 \pm 21,3 \mathrm{~b}$ \\
LVEd & $192,2 \pm 2,9 \mathrm{a}$ & $157,6 \pm 14,0 \mathrm{~b}$ & $200,0 \pm 22,9 \mathrm{a}$ \\
AVAd & $155,8 \pm 6,7 \mathrm{a}$ & $88,6 \pm 14,5 \mathrm{~b}$ & $97,7 \pm 14,1 \mathrm{~b}$ \\
AVEd & $164,1 \pm 2,6 \mathrm{a}$ & $117,2 \pm 20,3 \mathrm{~b}$ & $167,2 \pm 11,8 \mathrm{a}$ \\
\hline
\end{tabular}

Means between treatments in the rows, followed by different letters are different from each other at the $5 \%$ level by Tukey test.

\section{CONCLUSIONS}

1. The conversion of organic $\mathrm{S}$ to the sulfate form by the dry method in alkaline medium, using a mixture of $\mathrm{NaHCO}_{3}$ and $\mathrm{Ag}_{2} \mathrm{O}$ at $550{ }^{\circ} \mathrm{C}$ during $8 \mathrm{~h}$ and detection by turbidimetry were adequate to determine total $\mathrm{S}$ in soil samples.

2. The results of the Eschka mixture and of the substitution of $\mathrm{Ag}_{2} \mathrm{O}$ by $\mathrm{CuO}$ in the oxidation mixture were unsatisfactory.

\section{ACKNOWLEDGMENTS}

The authors are indebted to the FAPESP for the partial financial support and the infra-structure.

\section{LITERATURE CITED}

ABREU, M.F.; ABREU, C.A. \& ANDRADE, J.C. Determinação de fósforo, potássio, cálcio, magnésio, enxofre, cobre, ferro, manganês, zinco, níquel, cádmio, cromo e chumbo em ácido nítrico usando métodos da US-EPA. In: RAIJ, B.Van; ANDRADE, J.C.; CANTARELLA, H. \& QUAGGIO, J.A. Análise química para avaliação da fertilidade de solos tropicais. Campinas, Instituto Agronômico, 2001. p.251-261.

ALVAREZ V., V.H.; DIAS, L.E.; RIBEIRO JR., E.S.; SOUZA, R.B. \& FONSECA, C.A. Métodos de análises de enxofre em solos e plantas. Viçosa, MG, Universidade Federal de Viçosa, 2001. p.10-20.

BIEDERBECK, V.O. Soil organic sulfur and fertility. In: BIEDERBECK, V.O. Soil organic matter. Amsterdam, Elsevier, 1978. p.273-310.

EMPRESA BRASILEIRA DE PESQUISA AGROPECUÁRIA EMBRAPA. Centro Nacional de Pesquisa de Solos. Sistema brasileiro de classificação de solos. Brasília, Embrapa/Produção de Informação, 1999. 412p.

FRENEY, J.R. Forms and reactions of organic sulfur compounds in soils. In: TABATABAI, M.A., ed. Sulfur in agriculture. Madison, American Society of Agronomy, 1986. p.207-232. (Agronomy Monograph, 27)

NEPTUNE, A.M.L.; TABATABAI, M.A. \& HANWAY, J.J. Sulfur fractions and carbon-nitrogen-phosphorous-sulfur relationships in some Brazilian and Iowa soils. Soil Sci.Am. Proc., 39:51-55, 1975.

MOTT, R.A. \& WILKINSON, H.C. The use of Eschka method for determination of high sulfur contents. J. Appl. Chem., 3:218-223, 1953.

STEINBERGS, A.; ISMAA, O.; FRENEY, J.R. \& BARROW, N.J. Determination of total sulfur in soil and plant material. Anal. Chem. Acta, 27:158-167, 1962.

TABATABAI, M.A. \& BREMNER, J.M. An alkaline oxidation method for determination of total sulfur in soil. Soil Sci. Soc. Am. Proc., 34:62-65,1970.

TABATABAI, M.A. Sulfur. In: PAGE, R.L.; MiLLER, R.H. \& KEENEY, D.R. Methods of Soil Analysis: Chemical and Microbiological Properties. 2.ed. Madison, 1982. p.501538. 